\title{
MEDIDAS CAUTELARES INTERPRETATIVAS E DE EFEITOS ADITIVOS NO CONTROLE DE CONSTITUCIONALIDADE: UMA ANÁLISE CRÍTICA DE SUA APLICAÇÃO
}

\author{
Lucas De Laurentiis e Henrique Galkowicz
}

INTERPRETATIVE AND EFFECT ADDITIVES PRECAUTIONARY MEASURES IN CONSTITUTIONAL JUDICIAL REVIEW: A CRITICAL ANALYSIS OF ITS APPLICATION

\section{RESUMO}

APRESENTAMOS UMA ANÁLISE SISTEMÁTICA E CRÍTICA ACERCA DA POSSIBILIDADE DE TÉCNICAS DECISÓRIAS INTERPRETATIVAS E ADITIVAS SEREM APLICADAS EM MEDIDAS DE URGÊNCIA DO MODO PRINCIPAL DE CONTROLE JUDICIAL DE CONSTITUCIONALIDAdE. PARA TANTO, ESMIUÇAMOS AS CARACTERÍSTICAS DE TAIS TÉCNICAS PROCESSUAIS E AS PECULIARIDADES DE SUA APLICAC̣ÃO NAS AC̣ÕES TÍPICAS DA JURISDIÇĀO CONSTITUCIONAL BRASILEIRA. FEITO ISSO, AVALIAMOS A COMPATIBILIDADE DE TAIS PROVIMENTOS SUMÁRIOS COM AS PECULIARIDADES DAS TÉCNICAS DE CONTROLE INTERPRETATIVAS E ADITIVAS. ENFIM, APRESENTAMOS UM ESTUDO DE CASO, NO QUAL OS EFEITOS PRÁTICOS DE NOSSAS REFLEXÕES SÃO POSTOS A PROVA.

\section{PALAVRAS-CHAVE}

CONTROLE DE CONSTITUCIONALIDADE; MEDIDAS DE URGÊNCIA; TÉCNICAS DECISÓRIAS INTERPRETATIVAS E ADITIVAS.

\begin{abstract}
WE PRESENT A SYSTEMATIC AND CRITICAL ANALYSIS ABOUT THE POSSIBLE APPLICATION OF INTERPRETATIVE AND ADDITIVE DECISION-MAKING TECHNIQUES IN EMERGENCY MEASURES OF ABSTRACT CONSTITUTIONAL JUDICIAL REVIEW. TO REACH THIS GOAL, WE INSPECT THE MAIN CHARACTERISTICS OF SUCH PROCEDURAL TECHNIQUES AND THE PECULIARITIES OF ITS APPLICATION IN THE MAIN ACTIONS OF THE BRAZILIAN CONSTITUTIONAL JURISDICTION. AFTER THAT, WE EVALUATE THE COMPATIBILITY OF SUCH SUMMARIES DECISIONS WITH THE PECULIARITIES OF THE INTERPRETATIVE AND ADDITIVE CONTROL TECHNIQUES. FINALLY, WE PRESENT A CASE STUDY, IN WHICH THE PRACTICAL EFFECTS OF OUR THOUGHTS ARE TESTED.

\section{KEYWORDS}

JUDICIAL REVIEW; EMERGENCY MEASURES; INTERPRETATIVE AND ADDICTIVE DECISION-MAKING TECHNIQUES.
\end{abstract}

\section{INTRODUÇÃO}

Assistimos a um crescimento exponencial da produção doutrinária próxima das técnicas da jurisdição constitucional. Não há mais espaço para considerações gerais acerca das características dos sistemas de controle. As questões e ideias são cada vez mais profundas, polêmicas e, por isso mesmo, interessantes. Esse desenvolvimento tem 
ocorrido fundamentalmente em duas direções. Há quem proponha uma reavaliação do procedimento argumentativo da deliberação realizada nas Cortes constitucionais. A finalidade de tal análise é apontar possíveis déficits da argumentação desenvolvida no julgamento dos processos de controle de constitucionalidade, o que pode vir a comprometer a racionalidade e, consequentemente, a legitimidade das decisões que daí surjam. Mas há também quem se proponha a avaliar a utilização das técnicas e dos instrumentos que compõem o sistema de controle de constitucionalidade. O nível mais elementar dessa forma de análise é encontrado na exposição minuciosa de aspectos processuais ligados às demandas de controle principal de constitucionalidade. Existem incontáveis trabalhos com essa proposta. Hoje, essa é uma análise insuficiente. Com o desenvolvimento dos métodos de controle de constitucionalidade que combinam a modulação do sentido e do alcance das normas analisadas, surgem novos paradoxos teóricos e práticos, cujo reflexo direto é a instabilidade e insegurança das decisões da jurisprudência constitucional.

Aqui propomos uma reflexão que se aproxima de um desses pontos de tensão. Avaliaremos a admissibilidade do uso de técnicas interpretativas e de efeitos aditivos em sede de decisões cautelares de ações diretas de controle de constitucionalidade. De pronto, essa tarefa apresenta duas dificuldades. A primeira delas decorre do desenvolvimento do estudo e regulamentação das técnicas processuais de tutela sumária. O problema está em que dito movimento da ciência processual não foi devidamente acompanhado quer pelos analistas, quer pelos operadores da jurisdição constitucional. Passa despercebido aos olhos deles, por exemplo, que a distinção entre tutela cautelar antecipatória e conservativa não tem o caráter absoluto, antes apregoado por parte da doutrina. ${ }^{1}$ Mas isso não é tudo. Outras questões relevantes, como a legitimidade jurisdicional para conceder ex officio medidas cautelares, sejam elas assecuratórias ou antecipatórias, e a admissibilidade de provimentos sumários de natureza não cautelar nos processos de controle de constitucionalidade pela via principal, raramente são debatidas ou problematizadas pelos analistas de nosso sistema de controle de constitucionalidade. ${ }^{2}$

A seguinte hipótese poderia justificar esse fato. Parte da doutrina admite que as peculiaridades do sistema de controle de constitucionalidade principal afastam a incidência do regramento processual civil brasileiro. Com base nesse pressuposto, admite-se, por exemplo, que no processo objetivo não há partes, lide ou interesse jurídico a ser defendido (CLĖVE, 2000, p. 142;VELOSO, 1999, p. 68. MENDES, 2007, p. 156. Para uma perspectiva crítica acerca de tais ideias, ver: TAVARES, 2005, p. 399 e 400 ), que nele não ocorre qualquer forma de intervenção de terceiro, ${ }^{3}$ enfim que a decisão da Corte não pode ser desconstituída pela via da ação rescisória. ${ }^{4}$ Contudo, não nos parece que essas peculiaridades afastem o procedimento incidente no controle principal de constitucionalidade do modelo processual civil vigente. Isso porque o controle objetivo de constitucionalidade não deixa de ser uma forma de atuação 
jurisdicional da Corte Constitucional (RAMOS, 2010-b, p. 55; STERN, 1997, p. 15). Segue-se daí que o respeito ao procedimento e ao regramento processual em vigor é mais do que uma simples formalidade a ser cumprida na realização dos desígnios da jurisdição constitucional.

Na verdade, tal exigência é ainda mais premente no processo de controle de constitucionalidade, pois nele muitas vezes nos vemos confrontados com a necessidade de aplicação de conceitos abertos e indeterminados. Uma interpretação apressada de tal característica levaria à conclusão de que o processo de controle de constitucionalidade deve ter uma regulamentação autônoma, criada pelo próprio tribunal, para cada caso concreto. ${ }^{5}$ A despeito de tal prática ser comum não só na jurisdição constitucional brasileira, é justamente o contrário que deflui das características desses meios processuais: como o poder criativo das Cortes Constitucionais em relação ao resultado de seus julgamentos é elevando, o procedimento que rege seu processo decisório deve ser estritamente regulamentado (SCHLAICH; KORIOTH, 2010, p. 36). Sendo assim, o regramento processual prévio e baseado em pressupostos racionais deve ser considerado fator determinante da legitimação das decisões de qualquer esfera do exercício de poder estatal, inclusive a judicial. ${ }^{6}$ O recurso aos conceitos e regras da teoria geral do processo tem justamente essa finalidade.

É importante reter esta conclusão: o entendimento que nos parece ser correto no que diz respeito à correlação do sistema processual civil, seus pressupostos e institutos, com os julgamentos realizados na via de controle de constitucionalidade principal, é o de uma relação de complementariedade, não de mútua exclusão. ${ }^{7}$ Concebemos, portanto, que as características próprias às medidas urgentes, cautelares ou não, sejam fundamentadamente adaptadas aos processos objetivos de controle de constitucionalidade. Não que sua feição seja completamente alterada. De igual forma, e aqui adentramos no tema específico a ser tratado neste artigo, a admissibilidade das decisões manipulativas de sentido em sede de medidas cautelares de inconstitucionalidade pela via principal não pode desconsiderar as peculiaridades de tal técnica processual. Importa então verificar se tal compatibilidade existe, tarefa que comporta considerações práticas e teóricas.

Dividimos nossa análise nos seguintes passos. Em um primeiro momento, dirigimos nossas atenções para as características fundamentais das medidas urgentes admitidas no processo de controle objetivo de constitucionalidade. Os conceitos desenvolvidos nessa passagem servirão de fundamento para os argumentos e conclusões seguintes, nos quais abordaremos específica e separadamente a possibilidade de as medidas urgentes comportarem sentenças interpretativas e de efeitos aditivos. Após a análise de cada um desses itens, procuramos problematizar e avaliar um significativo precedente do Supremo Tribunal Federal tendo em vista os pressupostos teóricos por nós desenvolvidos. Com isso, julgamos demonstrar que as questões que ora apresentamos estão longe de serem quimeras teóricas. Ao contrário, o tema aqui proposto tem 
conteúdo e efeitos eminentemente práticos. As dificuldades de sua abordagem não podem, portanto, afastar a necessidade de seu imediato enfrentamento.

\section{i Características das medidas CAuTelares no PROCESSO OBJeTivo de CONTROLE DE CONTROLE DE CONSTITUCIONALIDADE}

Antes contestada por parcela da jurisprudência do Supremo Tribunal Federal, ${ }^{8}$ a medida cautelar em ações diretas de inconstitucionalidade teve seu fundamento constitucional ${ }^{9}$ consagrado pela Emenda Constitucional n. 7/77. ${ }^{10}$ A Constituição Federal de 1988 recepcionou essa possibilidade ao conferir ao Supremo a competência para julgar, originariamente, "o pedido de medida cautelar das ações diretas de inconstitucionalidade” (art. 102, I, p, da CF/1988). Mesmo frente ao silêncio desse dispositivo quanto à possibilidade da concessão de medidas liminares em ações declaratórias de constitucionalidade, a Corte considerou que "o poder de acautelar é imanente ao poder de julgar". ${ }^{11}$ Com base nesse fundamento, admitiu a possibilidade da concessão de medida cautelar em ações declaratórias de constitucionalidade, a despeito de o texto da Emenda Constitucional n. $3 / 93$ não prever a hipótese. ${ }^{12}$

A lei federal que regula o processo de controle abstrato de constitucionalidade no Brasil regulamentou dito instrumento processual (arts. 10 a 12 e 21 da Lei n. 9.868/99). Os requisitos que condicionam a concessão de tais medidas são comuns aos provimentos dessa natureza. O deferimento da medida liminar pressupõe a relevância dos fundamentos do pedido inicial (fumus boni iuris) e a necessidade de antecipação dos efeitos da tutela em face da possibilidade de prejuízo decorrente do retardamento da decisão postulada (BARROSO, 2006, p. 166), ou seja, para garantir a efetividade do resultado futuro e provável do julgamento (periculum in mora). ${ }^{13}$

Fora isso, a jurisprudência do Supremo também pauta as decisões de medidas liminares pelo que denomina "critério da conveniência", ${ }^{14}$ que envolve a ponderação entre o proveito e o ônus da suspensão provisória da norma questionada (BARROSO, 2006, p. 167). ${ }^{15} \mathrm{~A}$ doutrina constitucional tem afirmado que esse último requisito seria mais uma das especificidades do processo de controle de constitucionalidade. Assim não nos parece, contudo. Na verdade, a concessão de toda e qualquer tutela de natureza cautelar encontra-se sujeita à aferição dos ônus e benefícios que dela possam decorrer. $\mathrm{O}$ debate acerca da reversibilidade recíproca dessas decisões tem justamente esse pano de fundo: em casos em que tanto a concessão quanto a denegação da medida pleiteada importarem a ocorrência de danos de difícil ou improvável reparação, o julgador deverá pautar sua decisão por critérios e técnicas que tendam a aferir qual é o valor ou interesse de maior peso relativo no caso a ele apresentado. ${ }^{16}$

Admitida a possibilidade da concessão de medidas cautelares em ações declaratórias de constitucionalidade e inconstitucionalidade, o debate voltou-se para a análise da natureza de ditas medidas urgentes. $\mathrm{O}$ entendimento que prevaleceu afirma que 
tais provimentos jurisdicionais antecipam os efeitos práticos inerentes às decisões finais de mérito dessas demandas. ${ }^{17}$ Segundo a doutrina prevalente, tais provimentos são, portanto, decisões antecipatórias da tutela final do processo. Essa conclusão deve ser examinada com cuidado.

Há que se observar, antes de mais nada, que o conteúdo declaratório próprio das ações diretas não é passível de antecipação. O debate na doutrina processual a esse respeito foi intenso, sendo que alguns autores se inclinaram para a completa negação da possibilidade da concessão de tais medidas em demandas de tutela puramente declaratórias. O raciocínio, relativamente simples, que leva a essa conclusão pode ser resumido com a seguinte questão: se a finalidade da tutela jurisdicional declaratória é conferir certeza e estabilidade a uma relação jurídica controvertida, como podemos admitir que tal finalidade seja alcançada por meio de um provimento precário e de cognição superficial? (LOPES, 2007, p. 54 e 55) A resposta apresentada pela literatura processual busca distinguir os efeitos práticos da tutela declaratória de seus efeitos estritamente jurídicos. Nessa linha, Cassio Scarpinella Bueno explicita que, em decorrência da natureza da antecipação de tutela, "não há como antecipar o grau de certeza que só a sentença vai alcançar e que somente vai conseguir em virtude do desenvolvimento da ampla defesa, do contraditório e, enfim, após o exercício do devido processo legal. Antecipam-se, no entanto, efeitos fáticos, práticos ou jurídicos de uma declaração" (BUENO, 2011, p. 92 e 93. De forma similar, cf.: SILVA, 2005, p. 125).

Essa diretriz é plenamente compatível com o sistema de controle de constitucionalidade. De longa data, por exemplo, a doutrina constitucional alemã tem insistido em afirmar que o elemento decisivo para a concessão de medidas cautelares em sede de ações constitucionais é o "peso das desvantagens" (SCHLAICH; KORIOTH, 2010, p. 285) inerentes à manutenção ou suspensão da lei impugnada. O foco de tal juízo não é, portanto, a própria validade ou invalidade da norma, mas sua eficácia. $\mathrm{O}$ Ministro Moreira Alves seguiu à risca essa linha de pensamento ao afirmar que, "quando suspendemos liminarmente a vigência de uma lei, na realidade, não estamos declarando sua inconstitucionalidade, mas estamos apenas evitando que ela, a partir da concessão da liminar, produza efeitos negativos”. ${ }^{18}$

Ao que parece, algumas questões relevantes podem ser solucionadas com fundamento nessa diretriz. A primeira delas diz respeito à eficácia temporal das medidas urgentes proferidas em ações diretas. Não há qualquer incompatibilidade entre a previsão do efeito não retroativo dessa decisão (art. 11, § $1^{\circ}$, da Lei n. 9.868/99) e a natureza da sanção decorrente do vício de inconstitucionalidade, que permanece sendo a nulidade com efeitos aparentemente retroativos da norma questionada (RAMOS, 1994, p. 63). Pensar o contrário seria o mesmo que admitir que o conteúdo declaratório da decisão final possa ser antecipado pela medida cautelar. Como julgamos ter comprovado, não é isso o que ocorre. 
O segundo ponto relevante que pode ser adequadamente solucionado com a admissão do referido pressuposto está relacionado à cláusula de reserva de plenário (art. 97 da CF/1998). O questionamento apresentado por Clèmerson Merlin Clève a esse respeito é o seguinte: a previsão legal que autoriza a concessão da medida liminar pelo relator ad referendum da manifestação do Pleno contraria a exigência do julgamento da inconstitucionalidade pela sistemática da reserva de plenário? (CLÈVE, 2000 , p. 237). A resposta nos parece ser negativa. Primeiro, porque a regra que condiciona a eficácia das decisões de inconstitucionalidade à deliberação favorável da maioria dos membros da Corte, reunidos no órgão plenário ou especial, ${ }^{19}$ tem a finalidade de "evitar as flutuações decisórias que a variação de composição da corte propiciaria” (RAMOS, 2010, p. 191). Ora, é ínsita à natureza instrumental e precária da tutela cautelar a possibilidade de sua alteração ou revogação (BEDAQUE, 2009, p. 144). Sendo assim, a deferência ao legislador e a prudência que devem informar a decisão definitiva dos processos de controle de constitucionalidade, elementos esses que fundamentam a existência da cláusula de reserva de plenário, não podem ser transferidos sem temperamentos para as decisões cautelares de tais demandas. Nesses pronunciamentos, como já salientado, o que se encontra em questão são os efeitos nocivos de uma norma que pode se afigurar inconstitucional. Mas esse juízo, repita-se, não se identifica com a declaração do vício de incompatibilidade normativa, ato esse próprio ao julgamento definitivo, não ao cautelar. Por tudo isso, em nosso entender não há razão que sustente a inconstitucionalidade da previsão legal, na qual se autoriza a tomada de decisão liminar pelo relator da ação direta de inconstitucionalidade. ${ }^{20}$

O segundo questionamento a ser aqui avaliado gira em torno do conceito de periculum in mora aplicável aos processos de controle de constitucionalidade pela via principal. Parte da doutrina tem aventado a incompatibilidade desse conceito com o processo objetivo de controle de constitucionalidade. Tal conclusão teria fundamento na impossibilidade da análise de elementos de fato no interior do processo objetivo de controle de constitucionalidade (LUNARDI, 2006, p. 274). Pelas razões a seguir expostas, discordamos de tal posicionamento. Primeiramente, não há mais que se falar em uma pureza conceitual do regime de aferição abstrata de constitucionalidade. Como já salientado pela doutrina constitucional, o legislador brasileiro não adota uma leitura estanque e pura da sistemática abstrata do controle de constitucionalidade, pois "a aferição dos chamados fatos legislativos constitui parte essencial do chamado controle de constitucionalidade, de modo que a verificação desses fatos se relaciona íntima e indissociavelmente com o exercício do controle” (MENDES, 2007, p. 249). É o quanto bastaria para afastar a dúvida aventada contra a necessidade de aferição do periculum in mora no controle principal de constitucionalidade. Todavia, há mais a ser dito.

Não há como admitir dita conclusão, se tivermos como certo o pressuposto de que a tutela cautelar proferida em ações diretas não tem o condão de antecipar o 
conteúdo declaratório da decisão final do Tribunal. Como aqui reiteramos, essa decisão antecipa unicamente os efeitos práticos e sociais de tal medida. Com razão, portanto, adverte o Ministro Teori Albino Zavascki que as medidas liminares em ações de controle concentrado e principal de constitucionalidade "antecipam um, alguns ou todos os efeitos habilitados a operar reflexos no plano da realidade - ou seja, efeitos executivos - que podem decorrer da futura sentença de procedência” (ZAVASKI, 2001, p. 66).

Sendo assim, temos que a urgência da medida cautelar pleiteada em ações diretas tem íntima relação com os possíveis efeitos da norma impugnada. Para esse fim, o conteúdo da lei deve ser avaliado indireta e perfunctoriamente, sob pena de a medida cautelar vir a exaurir a matéria do julgamento principal. ${ }^{21}$ Nessa linha, a necessidade de aferição do periculum in mora em processos objetivos de controle de constitucionalidade nada mais representa do que o reconhecimento do caráter eminentemente acautelatório da medida liminar dessas demandas. Por isso, é de se estranhar a orientação da jurisprudência do Supremo Tribunal Federal, que é aceita sem grandes questionamentos pela doutrina nacional, segundo a qual o transcurso de considerável lapso temporal entre a edição do ato normativo e a propositura da ação direta desautoriza o reconhecimento do periculum in mora. ${ }^{22}$ Para se chegar à conclusão oposta, basta considerar que o tema principal da decisão cautelar não é a validade ou invalidade da lei, mas sim seus possíveis efeitos deletérios. Se esses realmente existem, não é o transcurso do tempo entre a edição da lei e a propositura da ação que vai apagálos. Ao contrário, essa situação pode muitas vezes agravar ou comprovar a urgência da medida pleiteada. Ademais, nem sempre os efeitos nocivos de um ato normativo surgem logo no momento de sua publicação, sendo possível que interpretações inconstitucionais surjam no decorrer sua vigência.

Finalmente, julgamos necessário tecer algumas observações acerca das diferenças existentes entre o regime das cautelares das ações diretas de inconstitucionalidade e das ações declaratórias de constitucionalidade. Se é certo que a cautelar das ações diretas de inconstitucionalidade efetivamente antecipam, total ou parcialmente, o conteúdo útil de seu provimento final, a sua concessão em ações declaratórias de constitucionalidade tem uma finalidade completamente diversa. Segundo o regramento dessa matéria, o efeito dessas últimas medidas é simplesmente suspender os julgamentos que envolvam a aplicação da lei questionada (art. 21 da Lei n. 9.868/99). Trata-se, portanto, de medida eminentemente assecuratória e de conteúdo mandamental (PALU, 2001, p. 256). A cautelar de ações de inconstitucionalidade, ao contrário, tem o condão de antecipar os efeitos práticos, ou executivos, da decisão final (CLÈVE, 2000, p. 238).

Ademais, a não concessão da cautelar pleiteada em ação direta de inconstitucionalidade não tem o mesmo efeito da sua concessão em ação declaratória de constitucionalidade. Não se admite, assim, a propositura de reclamação constitucional que 
tenha por fundamento a denegação liminar do pleito acautelatório produzido em ação direta de inconstitucionalidade, o que não ocorre quando se encontra em questão a preservação da eficácia de medida cautelar proferida em ações declaratórias de constitucionalidade. ${ }^{23}$

Esse quadro é um dos diversos problemas subjacentes à tese que atribui um "caráter dúplice” às ações diretas de controle principal de constitucionalidade. ${ }^{24}$ Como não se tem notícia de hipótese similar no direito comparado, ${ }^{25}$ cabe aos defensores dessa visão da sistemática de controle de constitucionalidade responder às seguintes indagações: se as ações diretas de controle de constitucionalidade e inconstitucionalidade são realmente "dúplices", por que a decisão denegatória da cautelar em ação de inconstitucionalidade não tem o mesmo conteúdo da decisão que concede a liminar em ação declaratória de constitucionalidade? A resposta esboçada por parte dessa corrente aponta para a incompletude da disposição legal que reconheceu a possibilidade da concessão de medida liminar em sede de ação declaratória de constitucionalidade. Nesse sentido, sustenta-se que dita medida cautelar teria, dentre outros, o efeito de suspender o andamento dos processos em que a lei analisada é aplicada (ZAVASKI, 2001, p. 63). Contudo, ao apreciar a constitucionalidade de lei que restringia a amplitude do poder geral de cautela em demandas que envolvam o Poder Público, o Supremo Tribunal Federal firmou entendimento no sentido da constitucionalidade daquelas normas justamente por considerar que cabe ao legislador delimitar os contornos e as hipóteses em que se afigura possível a antecipação dos efeitos da tutela. ${ }^{26}$

O dilema que se apresenta aos autores que pretendem sustentar o caráter bifronte das ações diretas de controle de constitucionalidade é, então, o seguinte: ou bem eles negam a relevância do referido pronunciamento do Supremo ou reconhecem que as cautelares das ações diretas são substancialmente diversas. O problema está em que a primeira opção é contrafatual e a segunda leva à consequência de que esses autores pretendem ver negada. A análise das soluções e interpretações possíveis desse intrincado problema ultrapassa os limites propostos neste artigo. Por isso, simplesmente apontamos sua existência e passamos a examinar o cabimento de decisões manipulativas em sede de medidas cautelares.

\section{CABimento de Decisões inTerpretativas EM SEDE DE MEDIdA CAUTElar}

Sem maiores embaraços, o Supremo Tribunal Federal tem se utilizado da interpretação conforme a Constituição em medidas liminares de ações diretas de constitucionalidade e inconstitucionalidade. ${ }^{27}$ Implicitamente, tal orientação pressupõe a identidade dos efeitos e do conteúdo das tutelas final e antecipada nas ações do modo principal de controle. Admitida tal identidade, não haveria razão para negar a admissibilidade da utilização de interpretações conforme a Constituição em tais provimentos 
liminares. Contudo, as premissas apresentadas no item antecedente nos levam à constatação de que essa não é uma orientação aceitável. A natureza do provimento liminar, cautelar ou antecipatório, é antagônica a um dos pressupostos teóricos do cabimento da interpretação conforme a Constituição. Há duas razões que levam a essa conclusão.

Primeiro, enquanto método de interpretação das leis, a interpretação conforme a Constituição somente pode ser aplicada após a fixação dos sentidos normativos possíveis. Ou seja, ela é uma técnica interpretativa que poderá ser manejada após a prévia utilização dos métodos convencionais de interpretação das leis. Nesse sentido, afirma-se que a interpretação conforme a Constituição constitui uma operação hermenêutica de aplicação subsidiária (GUSY, 1985, p. 217; MÜLLER, 1996, p. 121). Essa característica choca-se com a natureza superficial da cognição cautelar, pois a avaliação exaustiva de todos os sentidos normativos que decorram da utilização dos denominados métodos hermenêuticos clássicos está vedada nessa sede.

Mas essa conclusão não nos leva a excluir a possibilidade de as decisões cautelares comportarem a aplicação da chamada decisão de nulidade parcial sem redução de texto. Sabe-se que a jurisprudência do Supremo Tribunal Federal não diferencia essas técnicas com clareza, sobretudo quando elas são aplicadas no modo principal de controle. Contudo, em sede doutrinária, duas hipóteses foram construídas para fundamentar tal distinção. A primeira delas procura diferenciar a interpretação conforme a Constituição e a nulidade parcial sem redução de texto em função do direcionamento da tutela definitiva das demandas em que tais técnicas são aplicadas. Assim, se a decisão acolhe a inconstitucionalidade de sentidos da lei, a técnica a ser utilizada é a nulidade parcial sem redução de texto, mas, uma vez que se afirme a constitucionalidade de um dos sentidos normativos possíveis, a técnica será a interpretação conforme a Constituição. Nesses termos, pode-se sustentar que a nulidade parcial sem redução de texto é a face de uma moeda da qual a interpretação conforme a Constituição é a contraface.

Com base em uma segunda hipótese de diferenciação, enquanto a nulidade parcial sem redução de texto lida com a sanção de inconstitucionalidade de sentidos específicos e concretos da lei questionada, a interpretação conforme a Constituição trabalha com sentidos gerais e abstratos da norma (LEMBKE, 2009, p. 58). A discussão a respeito do acerto ou admissibilidade de cada uma dessas hipóteses de distinção no direito brasileiro ultrapassa os limites desse estudo (LAURENTIIS, 2012, p. 123 e ss.).

Todavia, cabe aqui observar que a adoção de qualquer dessas hipóteses necessariamente excluirá a possibilidade da interpretação conforme a Constituição ocorrer em sede de tutelas cautelares realizadas no modo principal de controle. Isso porque, em conformidade com a primeira hipótese de distinção, a interpretação de acordo com a Constituição nada mais configura que uma forma de negar provimento às decisões finais das ações diretas de inconstitucionalidade. Sendo assim, não seria nem mesmo 
possível ao autor da demanda de inconstitucionalidade pleitear a declaração de interpretação conforme a Constituição, vez que tal pedido conflitaria com o objetivo de tal demanda. Com base nesse fundamento, já se afirmou em sede jurisprudencial que falece interesse de agir ao autor que propõe ação direta com pedido de interpretação conforme a Constituição. ${ }^{28}$ Se tal conclusão é certa, quanto mais o será a que afirma a impossibilidade da demanda de interpretação conforme a Constituição em sede de tutela cautelar. Afinal, essa decisão nada mais representa do que a antecipação dos efeitos da tutela final daquelas ações. Como nesses provimentos finais a interpretação conforme a Constituição é inadmissível, nas decisões cautelares a utilização de técnica mostra-se igualmente incabível.

Conclusão semelhante, mas com fundamento diverso, deflui da segunda hipótese de distinção das técnicas interpretativas de controle. Isso porque, se a interpretação conforme a Constituição constitui uma técnica de controle que lida com o sentido abstrato e hipotético da lei questionada (MORAIS, 2011, p. 921), sua aplicação deve ser considerada subsidiária em relação tanto à nulidade parcial sem redução de texto quanto à própria declaração de inconstitucionalidade do texto da norma. Essa orientação é aceita por respeitável doutrina portuguesa, segundo a qual a opção entre as modalidades de decisões interpretativas não depende "de um mero juízo prudencial ou de oportunidade do Tribunal Constitucional. A preferência, no âmbito da fiscalização abstrata sucessiva, vai claramente para as decisões interpretativas de acolhimento" (MEDEIROS, 1999, p. 406). Em outros termos, a aplicação da interpretação conforme a Constituição deve ser duplamente subsidiária, pois ela "só ocorrerá quando o texto analisado não indicar claramente ser o caso de declaração pura e simples da inconstitucionalidade e, concomitantemente, não for também admissível a aplicação da técnica da nulidade parcial sem redução de texto”. (LAURENTIIS, 2012, p. 135)

Nessa linha, a decisão de interpretação conforme a Constituição pressupõe três requisitos visivelmente incompatíveis com a natureza dos provimentos cautelares.

Primeiro, ela demanda a avaliação em profundidade de todos os sentidos possíveis da lei questionada, operação que não se alinha com a superficialidade da cognição cautelar. Segundo, a decisão de interpretação conforme a Constituição envolve a manipulação do sentido último da norma, o que ocorre nos pronunciamentos declaratórios definitivos, e por isso mesmo constitui operação que se encontra fora do alcance da decisão cautelar, que toca, como já foi aqui observado, unicamente sua eficácia social potencialmente nociva. Em outros termos, como a decisão que suspende liminarmente a vigência de uma lei não declara sua inconstitucionalidade, mas apenas evita que sua aplicação produza efeitos negativos para a ordem jurídica, é necessário concluir que a interpretação conforme a Constituição não poderá ser aplicada em tais decisões. ${ }^{29}$

Os próprios requisitos processuais da aplicação da interpretação conforme a Constituição e da tutela cautelar em ações diretas são antagônicos. Enquanto a antecipação 
dos efeitos da tutela jurisdicional definitiva, ou a tutela cautelar do provimento jurisdicional, pressupõe a plausibilidade jurídica da tese apresentada na inicial, a interpretação conforme a Constituição deve sempre ocorrer em um estado de incerteza hermenêutica. Em outras palavras: a presença de um dos fundamentos da tutela liminar excluirá a possibilidade da aplicação da interpretação conforme a Constituição. De forma inversa, quando uma decisão de interpretação conforme a Constituição for admissível, a incerteza hermenêutica que circunda a possibilidade de sua aplicação excluirá a admissibilidade de um provimento liminar.

Reiteramos, todavia, que tais conclusões não têm o condão de afastar a possibilidade de aplicação das chamadas decisões de nulidade parcial sem redução de texto dos provimentos cautelares. Seja porque tais decisões, segundo a primeira hipótese de distinção, implicam o acolhimento da pretensão de declaração de inconstitucionalidade de um dos sentidos possíveis da lei, seja, por outro lado, em função da restrição de seus efeitos a uma aplicação determinada da norma questionada, essa técnica interpretativa de controle será inteiramente cabível em sede dessa cautelar. Exemplificando: ao debater a constitucionalidade da exigência imediata de emolumentos judiciais instituídos por leis de organização judiciárias, o Plenário do STF fixou entendimento unânime no sentido de que a exigibilidade de tais tributos deve respeitar a regra constitucional da anterioridade nonagesimal. ${ }^{30}$ Por duas razões, essa decisão contém uma aplicação típica da decisão de nulidade parcial sem redução de texto. Primeiro, tratase aí de uma decisão que suspende um sentido pontual e preciso da lei questionada, sem adentrar em seu conteúdo interpretativo geral e abstrato. Daí tratar-se de uma decisão apta a suspender a eficácia de um sentido específico e não explícito.

Em segundo lugar e em decorrência desse aspecto, tal decisão é circundada por um grau de certeza interpretativo absolutamente diverso daquele que encontramos nas decisões de interpretação conforme a Constituição. Tais decisões ocorrem em situações de incerteza interpretativa, que demandam a reconstrução do sentido da lei questionada. Com isso, as decisões de nulidade parcial sem redução de texto e interpretação conforme a Constituição podem ser apartadas em função do grau de plausibilidade de cada uma delas. Estas - decisões de interpretação conforme a Constituição - serão sempre decisões em que os sentidos possíveis da lei são igualmente plausíveis, mas diferentemente compatíveis com os parâmetros constitucionais. Aquelas - decisões de nulidade parcial sem redução de texto - podem ocorrer mesmo em situações de certeza interpretativa, que envolvam a desaplicação pontual de um dos aspectos da norma questionada. Por tudo isso, concluímos que, apesar de os elementos característicos da tutela cautelar serem avessos ao conceito de intepretação conforme a Constituição, não há qualquer incompatibilidade entre a nulidade parcial sem redução de texto e ditos provimentos jurisdicionais.

Por fim, um último aspecto digno de nota diz respeito à possibilidade de tutela cautelar proferida em sede de ações declaratórias de constitucionalidade comportar 
decisões de interpretação conforme a Constituição ou nulidade parcial sem redução de texto. Aqui devemos reter dois aspectos. Primeiro, um dos pressupostos processuais de admissibilidade de ações diretas de constitucionalidade é a existência de controvérsia fundada acerca da constitucionalidade da norma analisada. É o que se denomina na doutrina italiana de direito vivente (diritto vivente) inconstitucional, que nada mais significa senão a preexistência de aplicações da lei no sentido de sua inconstitucionalidade (MEDEIROS, 1999, p. 406; RAMOS, 2010-b, p. 270). Com base nessa premissa, a doutrina italiana tem afastado a realização de decisões interpretativas de rejeição - aqui denominadas por influência alemã de interpretação conforme a Constituição - quando existir um direito vivente inconstitucional. Nessas hipóteses, a Corte deve optar entre dois caminhos, ambos incompatíveis com adoção da interpretação conforme a Constituição: ou afasta o direito vivente inconstitucional e assim declara a constitucionalidade da lei, ou então aceita a proposta interpretativa desenvolvida pela jurisdição de base, afirmando, com isso, a inconstitucionalidade desses sentidos interpretativos específicos. No Brasil, em função da exigência legal da preexistência de controvérsia judicial fundada para que a ação declaratória de constitucionalidade seja admissível (art. 14, III, da Lei n. 9.868/99), a orientação perfilhada pelo direito italiano deve ser adotada. Com isso, a decisão proferida em dita demanda mostra-se incompatível quer com a aplicação da interpretação conforme a Constituição, quer com a nulidade parcial sem redução de texto. A incompatibilidade em relação à primeira dessas técnicas deriva da impossibilidade de a decisão interpretativa avançar sobre o sentido da inconstitucionalidade delineado pela jurisdição de base.

Não há que se cogitar igualmente da aplicação da nulidade parcial sem redução de texto já que a aplicação dessa técnica pressupõe a distinção entre o provimento que acolhe a inconstitucionalidade integral do texto legal e a inconstitucionalidade parcial, que não leva à redução de seu texto. Ora, como a ação declaratória de constitucionalidade sempre envolverá o acolhimento da impugnação de sentidos inconstitucionais da lei, sua procedência sempre implicará a afirmação da constitucionalidade do sentido da norma questionado. De outro lado, vez que sua improcedência afasta somente os sentidos controvertidos da lei analisada, afigura-se desnecessária a utilização da nulidade parcial sem redução de texto, já que tal decisão não acarretará, em regra, a afirmação da invalidade de toda a lei. Essa decisão representa simplesmente a aceitação dos sentidos inconstitucionais desenvolvidos previamente pela jurisdição em geral. Por fim, também aqui há o problema do interesse processual da demanda de nulidade parcial sem redução de texto em sede de ação declaratória de constitucionalidade: as finalidades dessa ação e daquela técnica são flagrantemente opostas.

Por tudo isso, parece-nos ser possível concluir que as decisões cautelares em ações declaratórias podem antecipar a declaração de inconstitucionalidade ou assegurar a eficácia do provimento final das decisões de declaração de constitucionalidade. 
Contudo, não é dado, em qualquer caso, aplicar a técnica da interpretação conforme a Constituição nesses provimentos. Fixadas essas conclusões, devemos agora avaliar o cabimento de decisões de efeitos aditivos em sede de tutela cautelar. Veremos que as conclusões não destoam do quanto afirmado com relação à interpretação conforme a Constituição.

\section{Cabimento da ATribuição de efeitos aditivos em decisão Cautelar}

As dificuldades que giram em torno do conteúdo das medidas cautelares proferidas no âmbito do processo objetivo de controle de constitucionalidade não se resumem às sentenças interpretativas. Também as chamadas sentenças de efeitos aditivos detêm peculiaridades que lhe retiram a possibilidade de manejo em decisões de caráter provisório do Supremo Tribunal Federal. Mas antes de demonstrarmos as razões para tal afirmação, é preciso delimitar o conceito desse tipo decisório que, a despeito de raramente aparecer explícito nas decisões do Supremo Tribunal Federal, ${ }^{31}$ é frequentemente proferido.

Varia na doutrina a terminologia para expressar o fenômeno aqui referenciado como efeito aditivo, ${ }^{32}$ que nada mais representa senão as decisões de inconstitucionalidade que, além de realizarem um juízo negativo de inconstitucionalidade (componente ablativo), agregam à norma remanescente a indicação de um critério jurídico que assegure a sua compatibilização com a Constituição - componente reconstrutivo (MORAIS, 2011, p. 411 a 412). Outros adjetivos, como "manipulativas", “aditivas”, “criativas”, "integrativas", entre outros, são frequentemente utilizados para expressar tal característica. Nenhum deles, porém, retrata a peculiaridade que se pretende abordar, seja por revelar uma demasiada abrangência ("manipulativas"), ${ }^{33}$ ou por traduzir uma inoportuna redução ("aditivas"), ${ }^{34}$ ou ainda pelo baixo índice de adesão e, portanto, de maior detalhamento, na doutrina (“criativas" e "integrativas"). ${ }^{35}$ Diante disso, conclui-se pela maior adequação da expressão efeitos aditivos, exatamente por ela traduzir um conceito de abrangência calibrada, ou seja, mais específica que o termo "manipulativas" - o que a diferencia das sentenças interpretativas e moduladoras dos efeitos temporais - mas, por outro lado, generosa a ponto de englobar uma variedade de subespécies decisórias, como a sentença aditiva em sentido estrito, ${ }^{36}$ a aditiva de princípio, ${ }^{37}$ a sentença substitutiva, ${ }^{38}$ a sentença demolitória ${ }^{39}$ e até mesmo as sentenças aditivas sem redução de texto, ${ }^{40}$ a qual se reaproxima da sentença interpretativa.

Não obstante as variações classificatórias, o fator mais importante para os fins deste artigo, e que serve como denominador comum para uma multiplicidade de decisões, é justamente o fato de, em determinadas circunstâncias, a jurisdição constitucional não se limitar a extirpar do ordenamento os conteúdos normativos incompatíveis com a Constituição. São casos em que órgão judicial vai além da simples declaração de inconstitucionalidade e produz um verdadeiro acréscimo de sentido às normas 
impugnadas, de sorte a agregar às suas decisões um elemento reconstrutivo (ou integrativo) incomum - ao menos de um ponto de vista tradicional do controle de constitucionalidade, que originalmente se consagrou como uma atividade que se limitava a reconhecer a nulidade das prescrições incompatíveis com a Constituição, e não a manipular seu alcance normativo para adequá-las aos parâmetros desta. ${ }^{41}$ Não é por outra razão que se discute até que ponto esse procedimento não consubstanciaria uma ilegítima atividade de legislar positivamente. ${ }^{42}$

Pois bem, feitas essas breves definições conceituais, é possível investigar com maior rigor a questão proposta no presente artigo, acerca da admissibilidade de medidas cautelares com efeitos aditivos na esfera do processo objetivo de controle de constitucionalidade.

Vimos que as medidas cautelares proferidas em ações diretas de inconstitucionalidade caracterizam-se por antecipar os efeitos práticos da decisão definitiva, de modo a lançar sobre a norma questionada um bloqueio da sua eficácia nociva. Ademais, observou-se que essa medida de natureza sumária não tem o condão de adiantar o conteúdo declaratório acerca da validade das normas infraconstitucionais, aspecto que é reservado à decisão definitiva, proferida após uma cognição exauriente da questão constitucional. ${ }^{43}$ Esse é um dos motivos pelo qual não seria possível prolatar uma decisão interpretativa em sede cautelar, tal como foi aqui amplamente examinado.

Dividida em duas partes, nem sempre claramente distinguíveis, a sentença de efeitos aditivos representa - tanto na etapa de recorte da norma quanto no momento de sua reformulação integrativa - um complexo ato de vontade com eficácia nitidamente declaratória. No primeiro desses momentos, porque a atividade jurisdicional faz um juízo acerca da validade das normas, que é o próprio objeto do processo objetivo de controle de constitucionalidade e, portanto, seu mérito. Já na segunda fase, porque o órgão jurisdicional ocupa-se de reconstruir a norma que acabara de ser parcialmente anulada, de sorte a transformar o significado originário do ato normativo (MORAIS, 2011, p. 415). Nesse passo, em que se declara qual o critério jurídico passível de ser justaposto ao segmento remanescente do regime normativo (MORAIS, 2011, p. 417), mais claro e inequívoco passa a ser o caráter de cognição aprofundada no que tange ao ordenamento jurídico e à validade de suas normas infraconstitucionais. Nesse sentido, ao indicar a solução conforme a Constituição que se extrai do ordenamento vigente (MEDEIROS, 1999, p. 478), a atividade jurisdicional revela uma atuação que ultrapassa a mera antecipação da eficácia bloqueadora do juízo de invalidade da norma impugnada, não se limitando, portanto, a obstar os efeitos nocivos (periculum in mora) da norma que aparenta (fumus boni juris) conter uma inconstitucionalidade.

Ora, somente após uma cognição plena e exauriente sobre o mérito da ação é que se torna possível a emissão de um juízo de certeza, e não de probabilidade ou verosimilhança (BEDAQUE, 2009, p. 122). Apenas depois de se analisar as razões de fundo da demanda é que se pode proferir um juízo declaratório acerca da validade das normas 
alegadamente incompatíveis (ações diretas de inconstitucionalidade) com a Constituição. Isso porque, ao se pronunciar sobre tais questões (eventualmente acolhendo as razões do autor), o julgador confere ao titular da ação uma tutela verdadeiramente satisfativa, e não acautelatória, visto que resolve a crise de direito material em exame (BEDAQUE, 2009, p. 113).

Por aí se vê que, se uma manifestação categórica sobre a inconstitucionalidade de uma norma é inadequada em sede de medidas cautelares, em que a jurisdição afirma aquilo que não pode ser legislado, com maior razão deve-se reputar inadequado o pronunciamento judicial que, em âmbito cautelar, manipula o sentido da norma impugnada, de sorte a afirmar aquilo que deveria ter sido legislado. Isso não apenas porque se trata de uma manifestação conflitante com a natureza dos provimentos urgentes de cognição sumária, conforme anteriormente ressaltado, mas também porque, ao pretender realizar uma atividade integrativa de preenchimento das lacunas normativas decorrentes da nulidade reconhecida, a jurisdição constitucional é excessivamente criativa, a ponto de os limites entre sua competência e as competências do Poder Legislativo e dos demais órgãos dos Poder Judiciário tornarem-se uma tormentosa questão constitucional. ${ }^{44} \mathrm{Tal}$ atitude configura, portanto, uma situação extrema para o sistema brasileiro de jurisdição constitucional, de sorte a aconselhar maior meditação por parte do Supremo Tribunal Federal.

\section{Estudo de CAso: ADI 3.854 (MC)}

No último tópico deste artigo, procuramos aplicar as ideias até aqui expostas a um caso recentemente revelado na jurisprudência do Supremo Tribunal Federal. Nossa intenção é evidenciar a atualidade e a importância prática da análise das questões abordadas ao longo deste artigo.

Com as Emendas Constitucionais n. 41/2003 e 47/2005, foram acrescentados novos patamares (teto e subtetos) aos subsídios dos agentes públicos de todos os entes federativos brasileiros, bem como de todos os poderes da República. Quanto ao Poder Judiciário dos Estados e do Distrito Federal, ficou determinado que os subsídios não poderiam “exceder o subsídio dos Desembargadores do Tribunal de Justiça, limitado a noventa inteiros e vinte e cinco centésimos por cento do subsídio mensal, em espécie, dos Ministros do Supremo Tribunal Federal” (art. 37, XI, da Constituição Federal de 1988).

A partir dessas reformas do texto constitucional, o Conselho Nacional de Justiça (CNJ) publicou duas resoluções que estabeleceram tetos remuneratórios diferenciados para os membros da magistratura estadual e os da federal, submetendo apenas os primeiros ao teto do subsídio mensal dos desembargadores do respectivo Tribunal de Justiça, o que ensejou a propositura pela Associação dos Magistrados Brasileiros $(\mathrm{AMB})$ da Ação Direta de Inconstitucionalidade n. 3.854, com pedido de medida 
cautelar, cujo objetivo foi impugnar as normas que estabeleciam a discriminação remuneratória entre os magistrados estaduais e os federais. O fundamento do pedido era a violação da isonomia.

No julgamento dessa medida cautelar, o Supremo Tribunal Federal, por maioria, nos termos do voto do relator, concedeu medida liminar com interpretação conforme a Constituição do art. 37, XI, da Constituição Federal, para excluir a submissão dos membros da magistratura estadual ao subteto de remuneração. Consequentemente, determinou-se a igualdade remuneratória entre os magistrados estaduais e federais de modo a restringir a aplicabilidade do teto em questão apenas aos demais servidores judiciários estaduais.

É patente a constatação de que o Supremo Tribunal Federal não se limitou a analisar a necessidade ou não do provimento de uma medida cautelar para suspender a eficácia das Emendas Constitucionais n. 41/2003 e 47/2005, bem como das resoluções do Conselho Nacional de Justiça, que efetuaram a discriminação que o tribunal reconheceu como "aparentemente" inconstitucional. Na realidade, uma leitura atenta do acórdão permite verificar que pouco se discutiu acerca da plausibilidade do pedido (fumus boni juris) e do perigo na demora da providência jurisdicional (periculum in mora). Diferentemente, o tribunal empreendeu uma análise aprofundada sobre o pedido final do demandante, argumentando sobre a compatibilidade do subteto com os ditames constitucionais da isonomia e da unidade nacional do Poder Judiciário. Tal atuação, por si só, justifica algumas das críticas feitas no decorrer deste trabalho, mas não é apenas isso.

Além de avançar sobre o mérito do processo e examinar a validade das emendas constitucionais (em vez de avaliar seus possíveis efeitos nocivos e a plausibilidade do pedido), o Tribunal proferiu uma sentença nitidamente interpretativa e de efeitos aditivos, o que Carlos Blanco de Morais chama de "sentença aditiva sem redução de texto". ${ }^{45}$ Isso fica evidente quando se verifica que o colegiado se manifestou no sentido de que não era o caso de se declarar a nulidade do texto normativo questionado, mas sim de afastar interpretações que consagrassem uma diferenciação entre magistrados federais e estaduais no que tange ao teto de seus subsídios. Tratava-se, portanto, de uma situação que, no entendimento do tribunal, requeria uma interpretação conforme a Constituição que destacasse o caráter unitário do Poder Judiciário brasileiro, tornando o ato normativo adequado a dito preceito. Por conseguinte, percebe-se que o tribunal não só definiu que a diferenciação entre os magistrados consubstancia uma aplicação inconstitucional das emendas, como também indicou critérios jurídicos aptos a transformar o sentido originário dos dispositivos, adequando-os à Constituição. Aqui, ficou manifesto o efeito aditivo da sentença prolatada pelo Supremo Tribunal Federal.

Pensamos que o Supremo Tribunal Federal, na medida cautelar em apreço, incorreu em diversos equívocos procedimentais, que geram graves incertezas acerca dos 
fundamentos e dos efeitos práticos de tal julgamento. Primeiramente, porque baralhou as tutelas de urgência e definitiva, de modo a apreciar o mérito da questão em uma decisão que, ao menos em princípio, foi instruída e estava designada apenas para uma análise liminar de cognição sabidamente superficial. Em segundo lugar, porque a técnica da interpretação conforme a Constituição utilizada pelo Supremo Tribunal Federal deve ser reservada para situações em que se constata um estado de incerteza hermenêutica (o que não é o caso pois a submissão da magistratura ao subteto estadual era um dado certo e que não gerou dúvidas a seus intérpretes, apesar de ter sido reputado inconstitucional), bem como deve ser considerada uma técnica subsidiária em face de outros provimentos possíveis, como a declaração de inconstitucionalidade, seja ela com ou sem redução de texto.

Por fim, ressaltamos que essa decisão contém efeitos aditivos e, por isso, vai muito além de um simples juízo de invalidade, ou mesmo de suspensão da eficácia, dos dispositivos impugnados. Com efeito, o Supremo Tribunal Federal não só caçou, como reconstruiu a norma analisada. Isso fica claro quando se verifica que o tribunal não se conteve em enunciar a inconstitucionalidade da submissão do subsídio dos magistrados estaduais ao subteto dos Estados e Distrito Federal, mas também colmatou a lacuna decorrente de tal juízo de invalidade parcial, equiparando os tetos da magistratura estadual e federal. Soma-se a isso o fato de que tal caso tratava da constitucionalidade de normas de índole constitucional, promulgados pelo poder constituinte derivado reformador. A despeito de isso não impedir o controle da constitucionalidade de tais normas, deve-se ressaltar que a autocontenção (self restraint) de tal pronunciamento jurisdicional há que ser elevado, sob pena de desconsiderar as escolhas do Poder constituinte (MENDES, 2008; VITA, 2007). Mas esse é só mais um dos problemas, dentre os muitos dessa decisão.

\section{CONSIDERAÇÕES FINAIS}

Percorridos os pontos anteriores, procuramos sintetizar as principais ideias e conclusões aqui desenvolvidas. Nossas primeiras considerações buscaram explicitar o regime jurídico a que estão submetidas as tutelas urgentes do modo de controle de constitucionalidade principal brasileiro. Vimos então que as medidas cautelares do processo objetivo apresentam características semelhantes àquelas típicas do processo civil, ou seja, visam resguardar a efetividade do resultado do processo e têm, como objeto próprio, a análise da relevância dos fundamentos do pedido inicial (fumus boni juris) e da necessidade de antecipação dos efeitos da tutela em face da possibilidade de prejuízo decorrente do retardamento da decisão postulada (periculum in mora). Fora elas, o Supremo Tribunal Federal também utiliza o chamado critério da "conveniência", que, ao nosso sentir, nada mais é do que uma manifestação da análise da reversibilidade recíproca das medidas cautelares. 
O ponto central de nossa argumentação diz respeito à natureza do pronunciamento cautelar. Sustentamos que o juízo de desvalor proferido no âmbito das medidas cautelares refere-se apenas à eficácia da norma impugnada, mais precisamente sobre os seus efeitos práticos e sociais, e não sobre a sua validade, ou inconstitucionalidade. Isso porque tais medidas jurisdicionais não têm o condão de antecipar o conteúdo declaratório típico das decisões definitivas proferidas no processo principal de controle de constitucionalidade.

Observamos então que a natureza do provimento liminar, seja ele cautelar ou antecipatório, choca-se com os pressupostos práticos e teóricos do cabimento da interpretação conforme a Constituição. É possível chegar a essa conclusão com base em duas hipóteses. Para a primeira delas, a interpretação conforme a Constituição consistiria numa técnica de controle de aplicação duplamente subsidiária, pois subordinada à impossibilidade de decisões de inconstitucionalidade pura e de nulidade parcial sem redução de texto. Esse fato impediria que decisões de interpretação conforme a Constituição sejam realizadas em sede cautelar, pois a plausibilidade desse provimento conflita com a incerteza interpretativa típica daquela técnica. Em uma segunda hipótese, a interpretação conforme a Constituição consistiria no juízo de improcedência da demanda de inconstitucionalidade de um sentido normativo. Isso faz com que não seja admissível quer o pedido de interpretação conforme a Constituição, quer o de medida cautelar nesse sentido, em sede de medida cautelar pleiteada em ações diretas de inconstitucionalidade. Vimos também que essa conclusão não pode ser estendida à nulidade parcial sem redução de texto. Finalmente, observamos que o cabimento de demandas de interpretação conforme a Constituição e nulidade parcial sem redução de texto é vedado em ações declaratórias de constitucionalidade.

Em seguida, verificamos que as sentenças de efeitos aditivos também são incompatíveis com o regime das medidas cautelares do processo principal de controle de constitucionalidade. Isso por duas razões. A primeira delas diz respeito à impossibilidade de antecipação do conteúdo declaratório típico da primeira etapa das sentenças de efeitos aditivos, que se caracteriza por anular parcialmente um texto normativo ou um segmento ideal da norma questionada. Em segundo lugar, porque a indicação de um critério jurídico para a reconstrução da norma e sua consequente adaptação ao parâmetro constitucional, ato característico da segunda etapa da decisão de efeitos aditivos, configura atividade não apenas de cognição aprofundada, como também demasiadamente criativa. Dentre outros, estes fundamentos demonstram a incoerência de julgamentos que, ao apreciarem medidas cautelares, implicam o acréscimo e a transformação do sentido da norma debatida. 


\section{NOTAS}

1 Com fundamento em amplo estudo do direito comparado, José Roberto dos Santos Bedaque observou, nesse sentido, que uma vez admitida a existência da "modalidade de providência destinada a satisfazer antecipadamente, não para solucionar o litígio, mas para assegurar que essa solução possa ocorrer de forma útil e eficaz, não se lhe pode negar o caráter acautelatório, ainda que provisoriamente satisfativo”. Isso porque, continua o citado autor, a "característica essencial dessa espécie de tutela jurisdicional está na sua inaptidão para representar solução definitiva para o litígio. Com ela, satisfaz-se faticamente, mas apenas para garantir a efetividade da satisfação jurídica. São cautelares, portanto, não apenas as conservativas, mas também aquelas destinadas a regulamentar provisoriamente o conflito, antecipando eventuais efeitos concretos da tutela final” (BEDAQUE, 2009, p. 312). Na doutrina nacional e de forma semelhante, vale conferir: LEONEL, 2010, p. 24 e ss.; CARNEIRO, 2010, p. 51. A disciplina das medidas urgentes no direito comparado segue diretriz semelhante, o que constatamos quando observamos a amplitude das tutelas cautelares amparadas pelos art. 700 do CPC italiano e pelo $\S 940$ da ZPO alemã. Cf. a esse respeito: TARZIA, 2000 , p. 212; TOMMASSEO, 1983, p. 140.

2 Apesar de não aceita, tal possibilidade foi debatida pelo Supremo no julgamento da ADI 4.628, relatada pelo Ministro Marco Aurélio e julgada em 8 de fevereiro de 2012. Posteriormente, todavia, o Plenário dessa Corte aceitou-a, ao menos implicitamente, ao converter o julgamento da cautelar requerida na ADI 4.163 em julgamento definitivo de mérito (Rel. Min. Cesar Peluso, j. 29.02.2012).

3 Contudo, o Supremo tem abrandado o rigor dessa vedação ao admitir a intervenção de amicus curiae nos processos objetivos de controle de constitucionalidade. Assim, decidiu-se que, não obstante as considerações doutrinárias acerca do caráter objetivo do modo de controle principal "cabe ter presente a regra inovadora constante do art. $7^{\circ}$, $\S 2^{\circ}$, da Lei n. 9.868/99, que, em caráter excepcional, abrandou o sentido absoluto da vedação pertinente à intervenção assistencial, passando, agora, a permitir o ingresso de entidade dotada de representatividade adequada no processo de controle abstrato de constitucionalidade (decisão monocrática do Min. Celso de Mello na ADI 2.130/SC, DJU de 02.02.2002).

4 Art. 26 da Lei n. 9.868/99.

5 Na avaliação de Dimitri Dimoulis e Soraya Lunardi, dita autonomia do processo de controle de constitucionalidade "não existe em termos sociológicos ou políticos. Tampouco existe do ponto de vista jurídico, pois o Tribunal Constitucional não é ‘Senhor do processo' (Herr seines Verfahrens), como incorretamente afirmavam, no início de suas atividades, o Tribunal Constitucional Federal alemão” (LUNARDI; DIMOULIS, 2013, p. 245).

6 Por isso, acentua Cândido Rangel Dinamarco que "o procedimento tem o valor de penhor da legalidade no exercício do poder" (DINAMARCO, 2005, p. 154).

7 A conclusão não destoa do quanto afirmado por Carlos Roberto de Alckmin Dutra, em obra que trata especificamente da análise dos princípios processuais aplicável ao processo de controle de constitucionalidade. Na síntese clara e coerente apresentada por esse autor: "Pode-se concluir que o processo de controle principal de constitucionalidade possui natureza especialíssima. Isso não impede, todavia, que sejam aplicadas, subsidiariamente, as regras do processo comum, quando não houver norma a regular a matéria; e quando as normas do processo com se adaptarem às especificidades do processo objetivo" (DUTRA, 2012, p. 103). De forma semelhante, Cassio Scarpinella Bueno aponta que é "preferível entender que os conceitos e os institutos do direito processual civil merecem ser devidamente contextualizados para guiarem adequadamente as discussões relativas às ações diretas de inconstitucionalidade", concluindo que "negar que existam partes, interesses, coisa julgada e tantas outras realidades inerentes a qualquer tema afeito ao direito processual civil é, com o devido respeito, pretender criar uma aura que em nada contribui para a correta compreensão e consequente funcionamento da ação direta de inconstitucionalidade" (BUENO, 2010, v. 2, t. III, p. 278). No direito constitucional alemão admite-se, a despeito das críticas doutrinárias, a possibilidade do Tribunal constitucional criar meios necessários à execução de seus julgados (BVerfGE 6, 300 (303 ff.). Contudo, tal possibilidade é expressamente restrita à regulamentação dos meios de execução das decisões proferidas nos processos da jurisdição constitucional alemã.

8 O Ministro Castro Nunes assentou no julgamento da Representação n. 94 que o pedido liminar de declaração de inconstitucionalidade no modo abstrato de controle é inadmissível, pois a "atribuição ora conferida ao Supremo Tribunal é sui generis, não tem por objeto ato governamental ou administrativo, senão ato constituinte ou 
legislativo; não está regulada em lei, que, aliás, não poderia dispor para estabelecer uma tramitação que entorpecesse a solução, de seu natural expedita, da crise institucional prefigurada” (Rp. 94, Rel. Min. Castro Nunes, DJ 11.07.1949). Posteriormente, no julgamento da medida cautelar na Representação n. 933/RJ (Rel. Min. Thompson Flores, Pleno, RTJ 076/342), o Supremo seguiu orientação oposta. Nessa ocasião, foram vencidos os Ministros Eloy Rocha, Xavier de Albuquerque e Bilac Pinto.

$9 \mathrm{O}$ art. $160, \S 1^{\circ}$, do Regimento Interno do STF, que no regime constitucional de 1969 tinha força de lei, já continha previsão autorizando a concessão de tais medidas urgentes.

10 Valendo-se do Ato Institucional de n. 5, o então Presidente da República, Ernesto Geisel, decretou o recesso do Congresso Nacional e aprovou duas reformas constitucionais. O episódio ficou conhecido como o "pacote de abril” de 1977. A Emenda Constitucional n. 8 distorceu a representação proporcional da Câmara dos Deputados e instituiu a eleição indireta para um terço dos senadores. A Emenda de n. 7 configurou uma minirreforma do Poder Judiciário que, dentre outras modificações, acrescentou ao elenco das competências originárias do Supremo Tribunal o julgamento do "pedido de medida cautelar nas representação oferecidas pelo Procurador-Geral da República" (art. 119, I, p, da CF/1969). A esse respeito, na doutrina, conferir: RAMOS, 2010-b, p. 222; BARROSO, 2006 , p. 64.

11 ADC-MC 4/DF, Rel. Min. Sydney Sanches, RTJ 76/342.

12 Discutiu-se em doutrina se a omissão constitucional no que diz respeito à medida cautelar em ações declaratórias de constitucionalidade impossibilitaria tal medida. A doutrina e a jurisprudência do Supremo pacificaram o entendimento segundo o qual a "deficiência da emenda constitucional é suprida pela aplicação de um regime tanto quanto possível idêntico à ação direta de inconstitucionalidade para a ação declaratória de constitucionalidade”, ademais "a possibilidade de liminares em ações de controle de constitucionalidade foi introduzida pela Emenda Constitucional n. 7/77, sendo certo que mesmo antes dessa previsão jurídica expressa o Supremo já as concedia, entendendo-as como instrumento indispensável da própria função jurisdicional” (TAVARES, 2011, p. 355). De forma semelhante, ver: VELOSO, 1999, p. 323.

13 Há discussão doutrinária com reflexos jurisprudenciais a respeito da natureza dos requisitos do processo cautelar. Adotamos aqui o entendimento de José Roberto dos Santos Bedaque, encampado por Márcio Louzada Carpena, para quem tais requisitos representam o mérito do processo. Cf. nesse sentido: BEDAQUE, 2009, p. 171; CARPENA, 2004, p. 145.

14 ADI-MC 568/AM, rel. Min. Sepúlveda Pertence, RDA 200/132.

15 Os mesmos requisitos são exigidos para a concessão de ordens provisórias (einstweilige anordnung) pelo Tribunal Constitucional alemão. Todavia, o que a doutrina e a jurisprudência constitucional brasileira impropriamente denominam “critério de conveniência”, lá se chama decisão de "dupla hipótese" (Doppelhypothese). Tal denominação indica com maior precisão a forma do raciocínio realizado pelo julgador, que deve confrontar o ônus e o benefício que sua decisão antecipatória acarretará, e ao mesmo tempo afasta a impressão de que dito julgamento estaria condicionado a uma avaliação puramente discricionária, o que efetivamente não ocorre. A esse respeito, confiramse: SCHLAICH; KORIOTH, 2010, p. 284; BÉGUIN, 1982, p. 158 e 159; LÖWER, 2005, p. 1.509.

16 Com acerto, portanto, afirmou Flávio Luiz Yarshell que em "casos de conflito de valores, portanto, será preciso confrontar os benefícios e malefícios da cessão e da denegação, recorrendo ao denominado princípio da proporcionalidade; o que, se não resolve inteira e satisfatoriamente essa complexa questão, representa, pelo menos, a busca de um critério atendo à preservação da efetividade dos provimentos jurisdicionais” (YARSHELL, 1998, p. 178).

17 Tal conclusão foi defendida, dentre outros, por Cândido Rangel Dinamarco, para quem a liminar em ações diretas de constitucionalidade e inconstitucionalidade seria um exemplo de "falsa cautelar" (cf. DINAMARCO, 2009, p. 62). De forma semelhante, na doutrina nacional, ver: ZAVASKI, 2001, p. 62; PALU, 2001, p. 240. Na jurisprudência, confiram-se, no mesmo sentido: ADI-MC 491/AM, Rel. Min. Moreira Alves, RTJ 137/100; Rp. 1.391/CE, Rel. Min. Célio Borja, RTJ 124/81. De forma semelhante, para Luís Roberto Barroso, a cautelar em ADC não afirma liminarmente "e com efeito vinculante, a constitucionalidade da norma impugnada" (BARROSO, 2006, p. 167), o que, inequivocamente, se confunde com o objeto da tutela pretendida nessa sede.

18 Rp. 1.391/CE, Rel. Min. Célio Borja, rel. para o acórdão Min. Moreira Alves, RTJ 124/81. 
19 Essa ressalva é importante, pois não basta, como pretendeu Lúcio Bittencourt, a manifestação da maioria dos membros da Corte (cf. BITTENCOURT, 1968, p. 45). Essa decisão deve ser proferida pelos órgãos especiais ou plenários, em cumprimento à regra de competência fixada pelo art. 481 do CPC.

20 Por isso e com as vênias de estilo, discordamos do entendimento, defendido por Carlos Roberto de Alckmin Dutra (2012, p. 177), segundo o qual as disposições regimentais de Tribunais de Justiça que confiram aos presidentes e relatores a competência para o julgamento das medidas cautelares são inconstitucionais.

21 A tendência, perigosa sob o prisma da segurança jurídica e do devido processo legal, preceitos e valores esses que induvidosamente também devem reger o processo constitucional de aferição da constitucionalidade, foi diagnosticada por: MENDES; VALE, 2011/2012, p. 14.

22 Cf., dentre outros julgamentos: ADI 1.935/RO, rel. Min. Marco Aurélio, DJU 11.07.1999.

23 Cf. RE 168.277-QO, Rel. Min. Ilmar Galvão, DJ 04.02.1998; RE 219.146, Rel. Min. Sepúlveda Pertence, DJU 16.04.1998.

24 A tese é conhecida. Dentre os inúmeros autores que a adotam, citamos: MENDES; MARTINS, 2007, p. 400. Para uma visão crítica a esse respeito, conferir: MESQUITA, 2005, p. 258 e ss; MARTINS, 2010, p. 135

25 Dita peculiaridade do sistema de controle de constitucionalidade brasileiro foi notada e criticada por Jorge Miranda, nos seguintes termos: "Voltado para a certeza do Direito e a económica processual, o instituto brasileiro apresenta-se bastante vulnerável: desde logo, porque, para tanto, bastaria atribuir força obrigatórias geral à não declaração de inconstitucionalidade; depois, porque diminui o campo de fiscalização difusa; e, sobretudo, porque o seu sentido útil acaba por se traduzir num acréscimo de legitimidade, numa espécie de sanção judiciária a medidas legislativas provenientes dos órgãos (salvo o Procurador-Geral da República) a quem se reserva a iniciativa. Não admira que seja controvertido" (MIRANDA, 2008, p. 81).

26 ADC-MC 4/DF, rel. Min. Sydney Sanches, DJ 21.05.1999.

27 Nesse sentido, vale conferir a seguinte jurisprudência do Supremo Tribunal Federal: ADI 4.178/GO, Rel. Min. Cesar Peluso, Pleno, DJe-050, 19.03.2010; ADI 4.167/DF, Rel. Min. Joaquim Barbosa, Pleno, DJe-079, 30.04.2009; ADC 12/DF, Rel. Min. Ayres Britto, Pleno, DJe-237, 18.12.2009.

28 Cf., nesse sentido, o voto do Ministro Eros Grau na ADI 3.026/DF, RTJ 201/100. Contudo, sem debater essa contradição processual, o STF tem admitido a postulação da interpretação conforme a Constituição em ações diretas de inconstitucionalidade. Decisão paradigmática a esse respeito foi proferida na ADI 4.277/DF, relator Ministro Ayres Britto, RTJ 219/212.

29 Tal conclusão já foi aceita em sede jurisprudencial em voto proferido pelo Ministro Moreira Alves na Questão de ordem debatida na Rp 1.391, rel. para o acórdão Ministro Moreira Alves, RTJ 124/80.

30 ADI 3.694/AM, Rel. Min. Sepúlveda Pertence, DJU 06.11.2006.

31 São exemplos de decisões em que os efeitos aditivos são identificados, ainda que com outras expressões: ADI 3.105; ADI 1.351 .

32 O termo é adotado por autores como Carlos Blanco de Morais (MORAIS, 2011, p. 411 e ss.) e Markus Gonzalez Beilfuss (BEILFUSS, 2000, p. 118 e ss.) e representa, ao mesmo tempo, algo maior que as sentenças aditivas em sentido estrito (modificativas), as sentenças substitutivas e outras, e também algo mais específico que as sentenças manipulativas (intermédias), que se referem a todos os tipos de sentença que vão além da mera declaração de invalidade de um texto normativo com efeito ex tunc. No caso, elas são identificadas por manipularem o sentido ou o efeito temporal das decisões e se localizarem.

33 Também chamadas intermédias, as sentenças manipulativas podem ser definidas como "as decisões jurisdicionais que determinam a modelação do sentido ou dos efeitos da norma submetida a julgamento" (MORAIS, 2011, p. 261). Trata-se, portanto, de um termo de amplo significado que inclui não só as sentenças de efeitos aditivos, mas também 
as sentenças interpretativas e as sentenças de modulação temporal dos efeitos da decisão (cf. MORAIS, 2011, p. 271; MEDEIROS, 1999, p. 457).

34 Conforme se verá, as sentenças "aditivas" representam apenas uma subespécie das sentenças de efeitos aditivos.

35 Tais expressões são citadas por Rui Medeiros com base da doutrina italiana (MEDEIROS, 1999, p. 457).

36 Em regra, quando se utiliza a expressão "sentença aditiva”, é dessa espécie que se trata. Diz respeito à decisão que visa suprir omissões relativas, pois tem como sua componente reconstrutiva a declaração de que a determinada norma é inconstitucional por deixar de estabelecer determinada medida que, segundo a Constituição, deveria prever. É dela que nos fala Rui Medeiros quando se refere às sentenças modificativas, por exemplo (1999, p. 456 e ss.). Na doutrina pátria, utilizam a expressão Roger Stiefelmann Leal (2006, p. 87 e ss.) e Elival da Silva Ramos (2010-a, p. 217).

37 São as decisões que, segundo Roger Stiefelmann Leal, declaram “a inconstitucionalidade de um ato normativo até que o legislador ultime novo diploma leal que estabeleça medida exigida constitucionalmente, segundo os princípios enunciados pela Corte" (LEAL, 2006, p. 89). Consoante Carlos Blanco de Morais, trata-se de um tipo de decisão: "i) que pressupõe a eliminação, em regra parcial, de uma norma inconstitucional; ii) que enuncia os limites da operação reparadora de uma omissão relativa ou de uma lacuna técnica; iii) mas que se abstém de proceder diretamente a essa reparação" (MORAIS, 2011, p. 442).

38 Por sentença substitutiva entende-se o tipo de sentença que declara a inconstitucionalidade "de uma norma enquanto, na parte ou nos limites em que contém um prescrição em vez de outra” (MEDEIROS, 1999, p. 456). Em outras palavras, é o tipo de sentença que "declara, por um lado, a inconstitucionalidade da norma na parte desta em que o Tribunal considera ser ilegítima e, por outro lado, acrescenta, em sua substituição, um critério de decisão diverso que deve ser conjugado com o segmento da norma não julgado inconstitucional” (MORAIS, 2011, p. 447).

39 Nas palavras de Carlos Blanco de MORAIS, as sentenças demolitórias definem-se como "sentenças redutivas com efeitos aditivos, dado que, ao eliminarem uma norma presente numa dada disposição, ampliam o âmbito aplicativo de outra norma (que pode ou não encontrar-se presente na referida disposição), cujo conteúdo se encontrava restringido pela primeira" (MORAIS, 2011, p. 423).

40 Mais uma vez, ressalta-se o conceito oferecido pelo supracitado Carlos Blanco de Morais: "as sentenças aditivas sem redução de texto supõem a eliminação do sentido normativo ideal emergente de uma disposição e a concomitante identificação, por parte da sentença de acolhimento, de uma norma ou segmento normativo que se encontrava em falta, dada a sua indispensabilidade para tornar o referido preceito conforme a Constituição" (MORAIS, 2011, p. 430).

41 Augusto Martín de la Vega descreve esta evolução da jurisdição constitucional como resultado da diferenciação entre enunciado prescritivo (texto legal) e normas, a qual permitiu a manipulação de conteúdos normativos a ponto de não mais se limitar a uma redução normativa. Em suas palavras: "En buena lógica, estos pronunciamientos deberían conducir a una 'reducción' del contenido normativo de la disposición. Ahora bien, una vez admitida desde muy pronto la capacidad de la Corte para realizar 'manipulaciones' del contenido normativo recabable de la disposición, era evidente que se abría el camino para que ésta emitiera pronunciamientos del mismo tipo, pero cuyos efectos normativos no fueran de reducción sino de ampliación o modificación de dicho contenido" (LA VEGA, 2003, p. 221).

42 Essa hipótese enseja um acalentado debate. Sobre o assunto, Rui Medeiros, por exemplo, afirma: "quanto às relações entre o poder jurisdicional e o poder legislativo, as decisões modificativas trazem para a ribalta o problema da admissibilidade de uma função jurisdicional paralegislativa e substitutiva daquela que cabe constitucionalmente ao legislador" (MEDEIROS, 1999, p. 477).

43 Sobre o assunto, afirma Roger Stiefelmann Leal: "As medidas cautelares adotadas em sede de controle abstrato de normas, porém, não têm por finalidade declarar a constitucionalidade ou inconstitucionalidade do ato normativo impugnado. Esta é função precípua das decisões de mérito” (LEAL, 2006, p. 162).

44 Esse é um ponto delicado e polêmico, sobre o qual não faltam análises doutrinárias. Exemplo disso são as investigações feitas por: ZAGREBELSKY, 1988, p. 299 e ss.; LA VEGA, 2003, p. 271 e ss.; MEDEIROS, 1999, p. 485 e ss. 
45 Percebe-se que a decisão do Supremo Tribunal Federal realizou todos os requisitos deste tipo decisório, pois eliminou um sentido normativo ideal e identificou uma norma ou segmento normativo que se encontrava em falta (isonomia e caráter unitário do poder judiciário) para, ao final, dar nova regulação ao caso, agora de acordo com a Constituição (MORAIS, 2011, p. 430).

\section{REFERÊNCIAS BIBLIOGRÁFICAS}

BARROSO, Luís Roberto. O controle de constitucionalidade no direito brasileiro: exposição sistemática da doutrina e análise crítica da jurisprudência. São Paulo, Saraiva: 2006.

BEDAQUE, José Roberto dos Santos. Tutela cautelar e tutela antecipada: tutelas sumárias e de urgência. 5. ed.. São Paulo: Malheiros, 2009.

BÉGUIN Jean-Claude. Le controle de la constitutionnalité des lois en République Fédérale d Allemagne. Paris: Economica, 1982.

BEILFUSS, Markus Gonzáles. Tribunal constitucional y reparación de la discriminación normativa. Madri: Centro de Estudios Políticos y Constitucionales, 2000.

BITTENCOURT, Lúcio. O controle jurisdicional da constitucionalidade das leis. 2. ed. Rio de Janeiro: Forense, 1968. BUENO, Cassio Scarpinella. Curso sistematizado de direito processual civil: direito processual público e direito processual coletivo. São Paulo: Saraiva, 2010, v. 2, t. III.

. Curso sistematizado de direito processual civil: tutela antecipada, tutela cautelar e procedimentos cautelares específicos. 3. ed.. São Paulo: Saraiva, 2011.

CARneIRO, Athos Gusmão. Da antecipação de tutela. 7. ed., Rio de Janeiro, 2010.

CARPENA, Márcio Louzada. Do processo cautelar moderno. Rio de Janeiro: Forense, 2004.

CLÈVE, Clèmerson Merlin. A fiscalização abstrata da constitucionalidade. 2. ed.. São Paulo: RT, 2000.

DINAmARCO, Cândido Rangel. A instrumentalidade do processo. 12. ed.. São Paulo: Malheiros, 2005. Nova era do processo civil. 3. ed.. São Paulo: Malheiros, 2009.

DUTRA, Carlos Roberto Alckmin. Controle abstrato de constitucionalidade: análise dos princípios processuais aplicáveis. São Paulo: Saraiva, 2012.

GUSY, Christoph. Parlamentarischer Gesetzgeber und Bundesverfassungsgericht, Berlin: Duncker und Humblot, 1985. LAURENTIIS, Lucas Catib de. Interpretação conforme a Constituição: conceitos, técnicas e efeitos. São Paulo:

Malheiros, 2012.

LEAL, Roger Stiefelmann. O efeito vinculante na jurisdição constitucional. São Paulo: Saraiva, 2006.

LEONEL, Ricardo de Barros. Tutela jurisdicional diferenciada. São Paulo: Revista dos Tribunais, 2010.

LEMBKE, Ulrike. Einheit aus Erkenntnis? Berlin: Duncker und Humblot, 2009.

LOPES, João Batista. Tutela antecipada no processo civil brasileiro. 3. ed. São Paulo: Revista dos Tribunais, 2007. LÖWER, Wolfgang. Zuständigkeiten und Verfahren des Bundesverfassungsgerichts. In: Isensee Josef, Kirchhof, Paul (Hrsg.), "Handbuch des Staatsrechts der Bundesrepublik Deutschland". Band III. Heidelberg: Muller Verlag, 2005 .

LUNARDI, Soraya Regina Gasparetto. Direito processual constitucional: problematização de sua autonomia, sua natureza e suas consequências. Tese, PUCSP, 2006.

MARTINS, Leonardo. "A retórica do processo constitucional objetivo no Brasil”. In: NOVELINO, Marcelo. Leituras complementares de Direito Constitucional: controle de constitucionalidade. 3. ed. Salvador: JusPodvim, 2010. MEDEIROS, Rui. A decisão de inconstitucionalidade. Lisboa: Universidade Católica Editora, 1999.

MENDES, Conrado Hubner. Controle de constitucionalidade e democracia. Rio de Janeiro: Elsevier, 2008.

"Desempenho deliberativo das cortes constitucionais e o STF". In: MACEDO JR., Ronaldo Porto;

BARBIERI, Catarina Helena Cortada. Direito e interpretação: racionalidades e instituições. São Paulo: Saraiva, 2011. MENDES, Gilmar Ferreira. Jurisdição constitucional. 5. ed.. São Paulo: Saraiva, 2007.

; MARTINS, Ives Gandra. Controle concentrado de constitucionalidade: comentários à Lei n. 9.868 de 10.11.1999. 2. ed. São Paulo: Saraiva, 2007.

; VALE, André Rufino do. "Questões atuais sobre as medidas cautelares no controle abstrato de constitucionalidade”. In: Observatório da jurisdição constitucional. Brasília: IDP, 2011/2012.

MESQUITA, José Ignacio Botelho de. “O desmantelamento do sistema brasileiro de controle de 
constitucionalidade”. Teses, estudos e pareceres de processo civil. São Paulo: Revista dos Tribunais, 2005.

MIRANDA, Jorge. Manual de direito constitucional: inconstitucionalidade e garantia da constituição. 3. ed.

Coimbra: Coimbra Editora, 2008.

MORAIS, Carlos Blanco de. Justiça constitucional. 2. ed. Coimbra: Coimbra Editora, 2011, t. II.

MÜLLER, Friedrich. Discours de la métode juridique. Paris: Presses Universitaires de France, 1996.

PALU, Oswaldo Luiz. Controle de constitucionalidade, conceitos, sistemas e efeitos. 2. ed.. São Paulo: Revista dos Tribunais, 2001

RAMOS, Elival da Silva. Ativismo judicial: parâmetros dogmáticos. São Paulo: Saraiva, 2010-a Controle de constitucionalidade no Brasil: perspectivas de evolução. São Paulo: Saraiva, 2010-b. A inconstitucionalidade das leis: vício e sanção. São Paulo: Saraiva, 1994.

SCHLAICH, Klaus; KORIOTH, Stefan. Das Bundesverfassungsgericht: Stellung, Verfahren, Entscheidung. München: C. H. Beck Verlag, 2010.

SILVA, Ovídio Baptista da. Curso de processo civil. 7. ed. Rio de Janeiro: Forense, 2005, v. I,

STERN, Klaus. Verfassunsgerichtsbarkeit und Gesetzgeber. Westdeutscher Verlag, 1997.

TARZIA, Giusepe. "Medidas cautelares atípicas: uma análise comparativa”. Revista de Processo, n. 99, jul.-set. 2000

TAVARES, André Ramos. Teoria da justiça constitucional. São Paulo: Saraiva, 2005. Curso de direito constitucional. São Paulo: Saraiva, 2011.

TOMMASSEO, Ferruccio. I provvedimenti d'urgenza: struttura e limiti dela tutela anticipatoria, Padova: Cedam, 1983.

VEGA, Augusto Martín de la. La sentencia constitucional em Italia. Madri: Centro de Estudios Políticos y Constitucionales, 2003.

VELOSO, Zeno. Controle jurisdicional de constitucionalidade. Belém: Cejup, 1999.

VITA, Álvaro. A justiça igualitária e seus críticos. São Paulo: Martins Fontes, 2007

YARSHELL, Flávio Luiz. "Antecipação de tutela específica nas obrigações de declaração de vontade, no sistema do CPC”. In: WAMBIER, Teresa Arruda Alvim (Org.). Aspectos polêmicos da antecipação de tutela. São Paulo: Revista dos Tribunais, 1998.

ZAGREBELSKY, Gustavo. La giustizia costituzionale. Bologna: Il Mulino, 1988.

ZAVASKI, Teori Albino. Eficácia das sentenças na jurisdição constitucional. São Paulo: Revista dos Tribunais, 2001.

\section{Lucas De Laurentiis}

São Paulo - SP - Brasil
lucas.laurentiis(agmail.com

São Paulo - SP - Brasi henrique.campos11@gmail.com
MESTRE E DOUTOR EM DIREITO CONSTITUCIONAL PELA Faculdade de Direito da Universidade de São Paulo.

Advogado.

\section{Henrique Galkowicz}

BACHAREL E MESTRE EM DIREITO CONSTITUCIONAL PELA Faculdade de Direito da Universidade de São Paulo. 